(2) Williams A. Quality-adjusted-lifeyears. Lancet 1987; ii: 1372. Williams further discusses the issue of 'Cost-effectiveness analysis: is it ethical?' in the Fournal of medical ethics 1992; 18: 7-11.

(3) Cubbon J. The principle of QALY maximisation as the basis for allocating health care resources. Fournal of medical ethics 1991; 17: 181-184.

(4) Lewis P A, Charny M. Which of two individuals do you treat when only their ages are different and you can't treat both? Fournal of medical ethics 1989; 15: 28-32.

(5) Goodman N. Resource allocation: idealism, realism, pragmatism, openness. Fournal of medical ethics 1991; 17: 179-180.

(6) Langford M J. Who should get the kidney machine? Fournal of medical ethics 1992; 18: 12-17.

(7) Black D. Paying for health. Fournal of medical ethics 1991; 17: 117-123.

(8) Warnock M A. A question of life: The Warnock report on human fertilisation and embryology, 1985. The findings of a public enquiry set up to make recommendations on the ethical problems emerging from new technology.
DR LEONIE V KATEKAR MBBS, BSc(Med), a Concerned Provider, a Concerned Decider, la Cumberland Avenue, Chilwell, Nottingham NG9 4DH

\section{Unprincipled QALYs: a response to Harris}

SIR

I should like to reply briefly to Professor

Harris's response to my article on QALY maximisation $(1,2)$.

Harris writes that it is an article of faith among QALY advocates that resources are scarce. That is the wrong way of putting it: the scarcity of resources is an inescapable part of the human condition. Consequently in any distribution of health services, there will be winners and losers; and if the distribution is rational, it will normally be possible to identify, at least by a description, those whose needs will not be completely met.

The word 'Utilitarianism' does not appear once in Harris's response. Yet my article was a fairly straightforward application of a maintstream version of that ethical standpoint (plus a few factual assumptions) to the problems of health care resource allocation. Arguably Utilitarianism is a product of the Industrial Revolution; but Utilitarian arguments are at least as old as Plato's Republic (3). Therefore I cannot believe that the essence of the approach for which I was arguing can be satisfactorily attacked with ephemeral slogans such as 'ageism', 'sexism' and 'Thatcherism'.

\section{References}

(1) Harris J. Unprincipled QALYs: a response to Cubbon. Fournal of medical ethics 1991; 17: 185-188.

(2) Cubbon J. The principle of QALY Maximisation as the basis for allocating health care resources. Fournal of medical ethics 1991; 17: 181-184.

(3) Plato. The Republic. Penguin: Harmondsworth, 1974.

JOHN CUBBON 135a Ashley Gardens, Thirleby Road, Victoria London SWIP IHN 